\title{
KARST IN RAS AL-KHAIMAH, NORTHERN UNITED ARAB EMIRATES
}

\author{
KRAS V RAS AL-KHAIMAHU, SEVERNI DEL ZDRUŽENIH \\ ARABSKIH EMIRATOV
}

\author{
Asma AL-FARRAJ ${ }^{1}$, Tadej SLABE ${ }^{2}$, Martin KNEZ ${ }^{2}$, Franci GABROVŠEK², Janez MULEC ${ }^{2}$, \\ Metka PETRIČㄹ, Nadja ZUPAN HAJNA²
}

\begin{abstract}
UDC 551.435.8(536.2)

Asma Al-Farraj, Tadej Slabe, Martin Knez, Franci Gabrovšek, Janez Mulec, Metka Petrič, Nadja Zupan Hajna: Karst in Ras Al-Khaimah, Northern United Arab Emirates

This paper presents karstological prospecting of selected areas in Ras Al-Khaimah Emirate, UAE. Several locations in Musandam Mountains have been explored for caves, karst springs and surface karst features. Two karst springs, Khatt and MeBreda, were analyzed for basic physical, chemical and microbiological parameters. Although they are both recharged from karst aquifers, they differ significantly. The first one is a thermal spring in which infiltrated rain water is mixed with more saline and mineralized water from greater depths. The location of the second one at the high altitude of $710 \mathrm{~m}$ a. s. 1. is conditioned by the existence of a less permeable zone within a carbonate aquifer with a larger share of dolomite. There were increased concentrations of nitrates probably due to grazing goats around the spring but on the other hand there was surprisingly low number of total bacterial counts; however detected Escherichia coli indicated probable fecal contamination. None of the water from any of the tested sites matched the ISO criteria for direct human consumption. Surface rock relief resulted from different karst processes was studied in river beds and side walls of wadis and on the mountain plateaus. The slopes of the wadis are often dissected by large recesses, relatively rare subsoil forms, and karren with microrills and rain flutes. More extensive karren are found on the tops of the mountains. The rocky riverbeds of wadis were shaped by rapid water currents and corrosion at the contact with sediment. In the study area at the northern slopes of mountains no big cave was found. The largest discovered cave was in fact tectonic fracture which was extended due to the gravitational sliding of part of a mountain along a fissure. But several small (10-20 m long) solutional caves have been discovered and surveyed on the wadis slopes. They exhibit relatively simple assemblage of dominantly deadend passages. Caves are vertically distributed at several levels
\end{abstract}

\begin{abstract}
Izvleček
UDK 551.435.8(536.2)

Asma Al-Farraj, Tadej Slabe, Martin Knez, Franci Gabrovšek, Janez Mulec, Metka Petrič, Nadja Zupan Hajna: Kras v Ras Al-Khaimahu, severni del Združenih Arabskih Emiratov

$\mathrm{V}$ članku predstavljamo preliminarne krasoslovne raziskave izbranih območij emirata Ras Al-Khaimah, ZAE. Na več lokacijah v Musandamskem gorovju smo raziskovali jame, kraške izvire in kraško površje. Kemične in mikrobiološke analize voda dveh kraških izvirov (Khatt in MeBreda) kažejo na precejšnjo razliko obeh vodozbirnih območij. Khatt je termalni izvir, za katere je značilno mešanje infiltrirane deževnice in globokih mineraliziranih voda. Izvir MeBreda se nahaja na nadmorski višini $710 \mathrm{~m}$ in iztekanje vode je pogojeno $\mathrm{z}$ manj prepustno dolomitizirano plastjo. Zaradi gorske paše je v vodi precej nitratov, vendar presenetljivo malo celokupnih bakterij. Prisotnost E. coli vseeno nakazuje verjetno fekalno onesnaženost. Nobena analizirana voda ne ustreza ISO standardom za neposredno uporabo za pitno vodo. $\mathrm{Na}$ gorskih planotah, pobočjih in koritih vadijev smo proučevali kraške skalne oblike. Pobočja vadijev so pogosto razčlenjena z velikimi vdolbinami, razmeroma redkimi podtalnimi oblikami ter škrapljami z mikrožlebiči in žlebiči. Obsežnejše škraplje so na vrhovih gora. Kamnite struge vadijev so oblikovali hitri vodni tokovi in korozija ob stiku $\mathrm{z}$ naplavino. $\mathrm{Na}$ severnih pobočjih obravnavanega območja nismo našli večjih jam. Največja odkrita jama je v sistemu razpok, ki so nastale zaradi gravitacijskega drsenja dela gore $\mathrm{v}$ dolino. $\mathrm{V}$ dolinah vadijev smo našli več pravih kraških jam (dolžina 10 do 20 m). Največkrat gre za enostavno, slabo razvejano geometrijo. Rovi se povsem slepo končajo. Jame so vertikalno razporejene po različnih nivojih glede na dno vadija. Skalne oblike kažejo na paragenetski razvoj. Več jam je povsem ali delno napolnjenih z rumenim klastičnim sedimentom. Našli smo tudi plasti sige ter kristale kalcita in sadre. Mineraloška analiza je pokazala precej podobno sestavo vzorcev. V njih smo v različnih razmerjih določili združbo kremena, sadre, kaolini-
\end{abstract}

\footnotetext{
${ }^{1}$ UAE University, UAE, e-mail: asma@uaeu.ac.ae

${ }^{2}$ Karst Research Institute ZRC SAZU, Titov trg 2, 6230 Postojna, Slovenia,

E-mails: slabe@zrc-sazu.si (Tadej Slabe), petric@zrc-sazu.si (Metka Petrič), zupan@zrc-sazu.si (Nadja Zupan Hajna), gabrovsek@zrc-sazu.si (Franci Gabrovšek), knez@zrc-sazu.si (Martin Knez), janez.mulec@guest.arnes.si (Janez Mulec), asma@uaeu.ac.ae (Asma Al Farray)
}

Received/Prejeto: 03.05.2013 
above the wadis. The rocky relief of the caves indicates the paragenetic development of the caves. Some of the studies caves were fully and some partially filled with yellow clastic sediments. Also few layers of flowstone, calcite crystals and gypsum crystals were found. Mineralogical analyses shows very similar composition of sediments: different minerals such as quartz, gypsum, kaolinite, smectite, illite, calcite and palygorskite in various proportions. Calcite and gypsum represent precipitates from the cave (crusts, crystals, cements) and the other minerals were brought to the cave most probably by water or wind from eroded rocks and/or soils from wadis catchment areas.

Key words: karst in arid climate, wadi, karst springs, caves, rock features, United Arab Emirates. ta, smektita, ilita, kalcita in paligorskita. Kalcit in sadra sta se verjetno izločila $\mathrm{v}$ jami, ostali minerali so produkti preperevanja kamnin $\mathrm{s}$ širšega območja vadija, $\mathrm{v}$ jame so preneseni $\mathrm{z}$ vodo in/ali vetrom.

Ključne besede: kras v aridni klimi, vadi, kraški izviri, jame, skalne oblike, Združeni Arabski Emirati.

\section{INTRODUCTION}

Dominated by a north-south alignment of mountain ridges, the Oman Mountains are the highest area in the
UAE; the highest picks of the mountains reach above 2,000 $\mathrm{m}$ a.s.l. Our study area is located in Ras Al-Khaim-

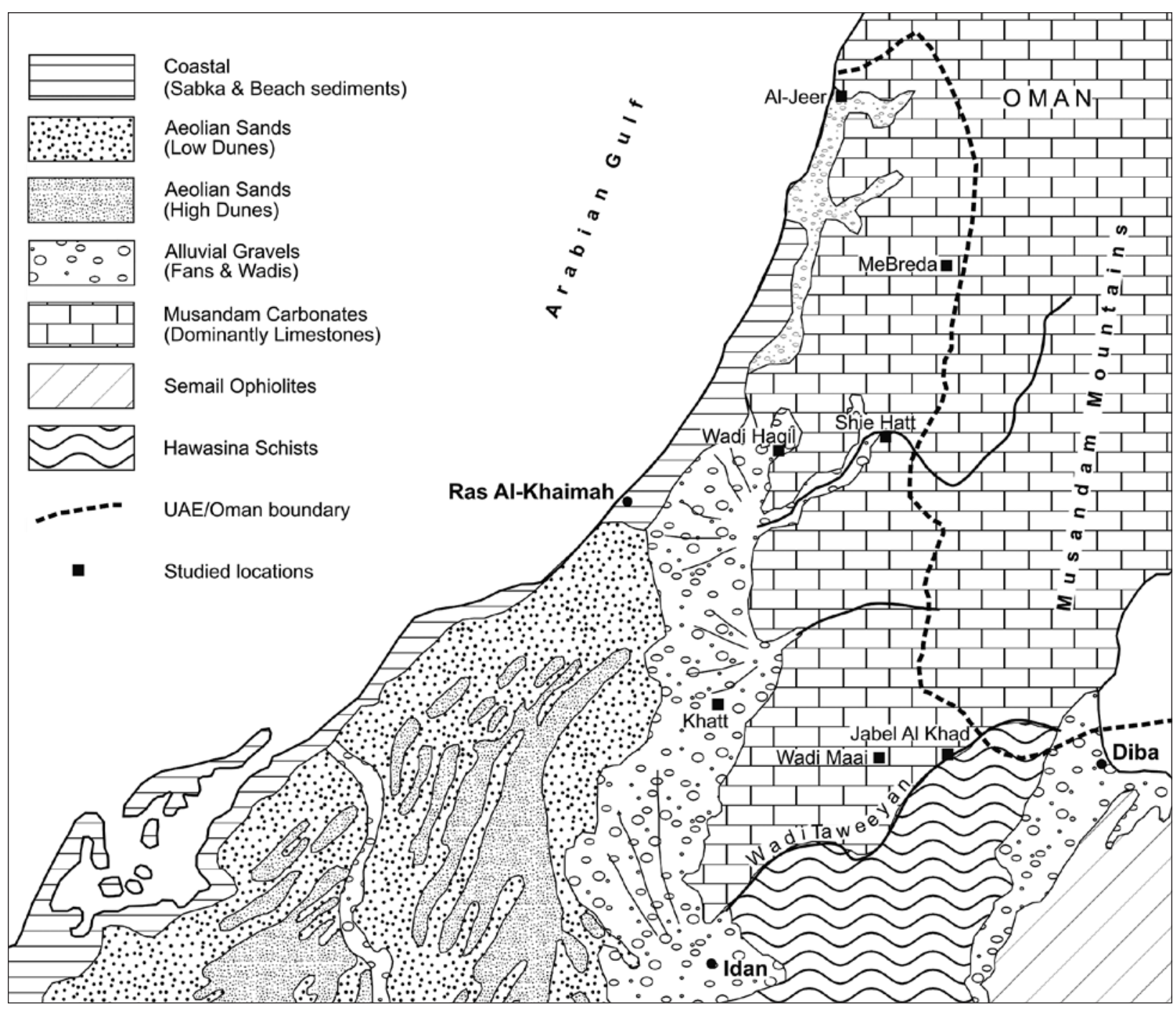

Fig. 1: Locations of the study areas with major lithology (adopted from The National Atlas of the United Emirates, 1993). 
ah in northern UAE (Fig. 1) in the Musandam Mountains.

The present climate of the northern UAE is highly arid, with summer temperatures reaching $50{ }^{\circ} \mathrm{C}$ and winter temperatures rarely below $14^{\circ} \mathrm{C}$. Rain is irregular and infrequent and occurs mainly in winter. The average annual rainfall is $135 \mathrm{~mm}$ on the $\mathrm{W}$ side of the mountains and $129 \mathrm{~mm}$ in Dibba (E side), but can be higher at higher altitudes, e.g., $166 \mathrm{~mm}$ in Wadi Al-Bih (Ministry of Communications 1996). The mean annual surface run-off is $19 \mathrm{~mm}$ in Wadi Al-Bih (Ministry of Agriculture 1993). Flash floods occur once or twice a year in wadis such as Wadi Al-Bih. In other wadis they may be as rare as once every ten years (Meigs 1952).

Several studies have been done on caves and karst in the Arabian Peninsula. The most extensive research has been done in Saudi Arabia (Edgell 1990; Forti et al. 2005; Kempe \& Dirks 2008). In Oman, most recent studies were done on speleothems related to climate change studies (e.g., Fleitmann \& Matter 2009; Fleitmann et al. 2003; Burns et al. 1998, 2001; Sadiq \& Nasir 2002; Embabi \& Ali 1990).
Karst and caves in the United Arab Emirates (UAE) are poorly explored (Zupan Hajna et al. 2013). The existing studies have been mainly undertaken by the Emirates Natural History Group in Jebel Hafit (e.g., Jeannin 1992; Waltham \& Jeannin 1998; Fogg et al. 2002; Aspinall \& Hellyer 2004). In the northern UAE little investigation has been done on caves or karst as is seen from existing literature. Swiss expedition in the beginning of 90's reported minor speleological findings (Jeannin 1992).

This paper presents findings and observations of January 2011 field campaign aiming to locate, explore and map new caves and other karst features in northern UAE, more precisely in northern slopes of Musandam Mountains (Fig. 1). One of the goals of our study was also to look for karst areas or locations with potential use for tourism. The exploration and study areas were on the northern slopes of Mount Al Jeer; in Wadi Haqil; in the area of Wadi Bih and its tributaries Wadi Shehah (MeBreda) and Wadi Shie Haft; and in area of Wadi Taweeyan and its tributary Wadi Maai (Fig. 1).

\section{A BRIEF GEOLOGICAL OVERVIEW}

Oman and the UAE are located on the NE margin of the Arabian plate (Ricateau and Riche 1980; Kusky et al. 2005). This plate is bounded to the south and SW by the active spreading axes of the Gulf of Aden and Red Sea. On the east and west its border is marked by transcurrent fault zones. Northern edge of the plate is marked by a complex continent-continent to continent-ocean collision boundary along the Zagros and Makran fold and thrust belts. The Northern Oman Mountains were formed by two distinct orogenic events separated by a period of tectonic quiescence. These events are the Late Cretaceous ophiolite obduction tectonics of the Oman Mountains and the Dibba zone, and the Cenozoic thrusting phase associated with the Zagros orogeny, which took place predominantly during the Oligocene-Miocene (Searle et al. 1983; Searle, 1988). As a result, the present Northern Oman Mountains consist of several major tectono-stratigraphic units (sensu Breton et al. 2004) as a pre-Permian Basement, the Hajar Unit, the Hawasina Nappes, the Samail Ophiolite and metamorphic sole, and the postnappe structural units.

The Musandam Mountains, which represent northeast part of Oman Mountains spreded east of Dibba fault zone. The Musandam Carbonates were deposited in shallow water on the Arabian continental margin. The Samail Ophiolite represents a portion of the Tethyan ocean crust formed at a spreading center of Middle Cretaceous age (Cenomanian). During the late Cretaceous the ocean closed and the Musandam Carbonates and Semail Ophiolites were tectonically shifted over the Hawasina Unit (Glennie et al. 1974).

The present-day topography is believed to have developed during a later Cenozoic orogenic event (Breesch et al. 2009). The emergence and uplift of the Musandam Peninsula in the Miocene caused the initiation of the drainage network in the northern UAE. However, the UAE-Oman mountain range has only been a barrier for the last fifteen to twenty million years, which has also influenced the climatic conditions there.

In the Pleistocene, huge terraces of alluvial sediments accumulated in wadis at the feet of the Musandam Mountains (Al-Farray \& Harvey 2000, 2004). The limestone mountain ranges are dissected by wadis of various sizes ranging from smaller gorges to large valleys, which present a unique image of fluvial relatively densely dissected karst. Unique caves with characteristic rock relief forms developed in their slopes.

Our studied areas were dominated by carbonate rocks of the Musandam Group (Lower, Middle, Upper Musandam limestone) of Upper Jurassic to Lower Cretaceous age; carbonates of the Russ al Jibal Group (Bih dolomites, Haqil limestone, Ghail limestones) of Middle Permian to Middle Triassic age; and of the Elphinstone Group (Milaha limestone, Ghalilah limestones and mud 
Tab. 1: Calcimetric Complexometric data on rock from the slopes of Mount Al Jeer, Wadi Tawiyeen, Jebel Al Khab area and Wadi Maai.

\begin{tabular}{|c|c|c|c|c|c|c|c|}
\hline Rock sample & $\mathrm{CaO}(\%)$ & $\mathrm{MgO}(\%)$ & Dolomite (\%) & Calcite (\%) & Total carbonate (\%) & $\mathrm{CaO} / \mathrm{MgO}$ & $\begin{array}{l}\text { Insoluble } \\
\text { Residue (\%) }\end{array}$ \\
\hline Al Jeer 1-1 & 55.29 & 0.12 & 0.55 & 98.38 & 98.93 & 460.75 & 2.07 \\
\hline Al Jeer 1-2 & 47.78 & 4.75 & 21.76 & 73.44 & 95.20 & 10.05 & 4.80 \\
\hline Al Jeer 1-3 & 33.87 & 15.40 & 70.45 & 22.21 & 92.66 & 2.20 & 7.34 \\
\hline Tawiyeen 3-1 & 48.51 & 1.29 & 5.90 & 84.37 & 89.27 & 37.60 & 10.73 \\
\hline Tawiyeen 3-2 & 52.66 & 0.40 & 1.84 & 92.97 & 94.81 & 131.65 & 5.19 \\
\hline Tawiyeen 3-3 & 49.79 & 0.32 & 1.74 & 88.78 & 89.52 & 155.59 & 10.48 \\
\hline Tawiyeen 3-4 & 51.31 & 0.60 & 2.76 & 90.06 & 92.82 & 85.52 & 7.18 \\
\hline Tawiyeen 3-5a & 54.17 & 0.64 & 2.95 & 95.06 & 98.01 & 84.46 & 1.99 \\
\hline Tawiyeen 3-5b & 49.07 & 0.40 & 1.84 & 86.57 & 88.41 & 122.67 & 11.59 \\
\hline Jebel Al Khab 4-1 & 55.18 & 0.32 & 1.47 & 96.49 & 98.98 & 172.43 & 1.02 \\
\hline Jebel Al Khab 4-2 & 54.84 & 0.36 & 1.66 & 96.96 & 98.62 & 151.55 & 1.38 \\
\hline Maai 5-1 & 54.62 & 0.24 & 1.11 & 96.70 & 97.81 & 227.58 & 2.19 \\
\hline Maai below 5-2 & 55.01 & 0.68 & 3.13 & 95.47 & 99.60 & 80.89 & 0.40 \\
\hline Maai above 5-2 & 54.79 & 0.64 & 92.95 & 0.88 & 99.12 & 85.61 & 0.88 \\
\hline
\end{tabular}

stones) of Upper Triassic to Lower Jurassic age (Hudson \& Chattan 1995; Hudson 1960).

Thirty-nine samples were taken at 6 study areas to make fifty-nine microscopic thin-sections that were examined from the petrological and lithostratigraphic aspects to study the causes of selective karstification at lithostratigraphic contacts of the rock and to see if there were any significant ones. All samples were also subjected to calcimetric complexometric analyses. The limestone at Mount Al Jeer is homogeneous mudstone, intramicrite with quartz inclusions, with some dolomitized layers with more than $70 \%$ dolomite content (Tab. 1). The main structures of limestones at Wadi Haqil are oolites and pisolites which can be traced throughout almost the entire profile (grainstone to packstone, oobiopelintrasparite to oobiopelintramicrite). It is only in the upper part that the oolite-pisolite limestones changes into slightly dolomitized micrite to microsparite rock with a slightly lower content of total carbonate and a significantly increased percentage of dolomite and insoluble residues. Limestones from Wadi Tawiyeen were homogeneous and compact (mudstone, micrite), and its profile shows no distinct changes. Some samples show younger calcite fillings. All of them, however, contain a significant percentage of insoluble residues that in most cases per- tain to quartz. Oolite limestone at Jebel Al Khab (grainstone to packstone, oosparite to oomicrite) contains a high amount of calcium carbonate (Tab. 1). Ooids are usually 15 to $40 \mu \mathrm{m}$ in diameter in the layer below the contact and 40 to 70 or $90 \mu \mathrm{m}$ in the layer above the contact along which initial karstification is evident. Strongly recrystallized limstones were found in the Wadi Maai (grainstone to packstone, biointrapelmicrite to biointrapelsparite), The calcite content below the bedding plane along which the pocket formed is above $95 \%$ (Tab. 1). The rock above this bedding plane has largely the same properties as the rock below it but displays intensive dolomitization. In the area of the MeBreda spring we studied a cave in Wadi Shehah that opened during a recent slide of the slope. The profile has alternating layers of mudstone, wackestone, and packstone or intrapelbiomicrite, intrabiomicrite, and intrabiopelmicrosparite, respectively, up to one meter thick. Only the highest section of the studied profile of the rock displays a high content of calcite (Tab. 1).

The main result was that the samples contain shallow sea carbonates which were partly recrystallized and dolomitized and there was no emphasises influence on karstification of the surface or formation of first initial cavities.

\section{HYDROGEOLOGICAL CHARACTERISTICS AND WATER QUALITY}

Hydrogeological characteristics of the UAE are significantly influenced by low amount of precipitation and high potential evaporation. Practically all rain water drains as surface flow in a form of seasonal floods, and according to some estimations only 2 to $3 \%$ of it recharges the groundwater (Rizk \& Alsharhan 2003). 

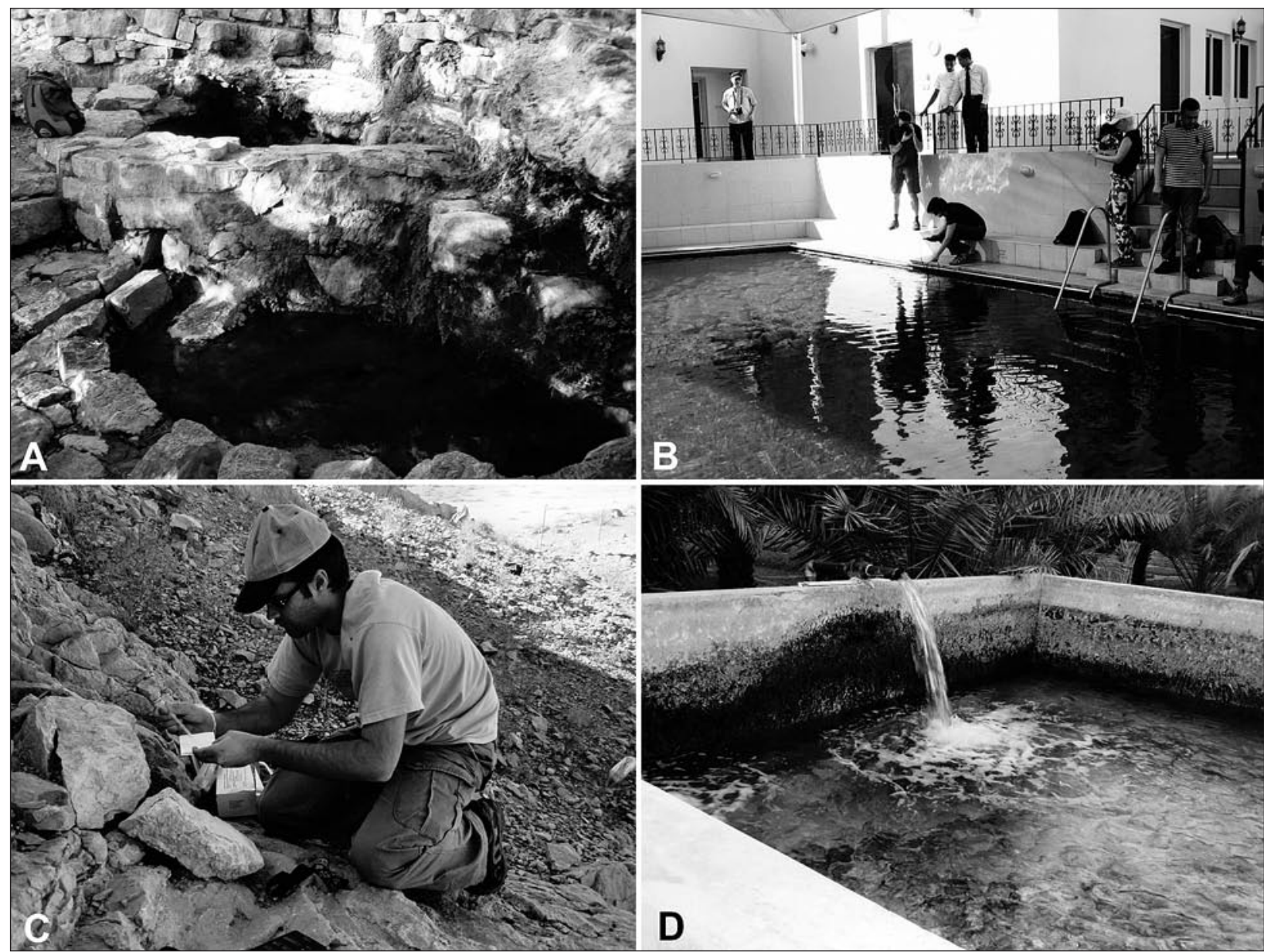

Fig. 2: Sampling sites: a) Two pools of the MeBreda spring in desert mountains above the Wadi Shehah. b) Spa resort at the Khatt spring. c) Sampling from a rainwater trap in the Wadi Haqil, and d) Water pumped from a gravel aquifer in the Wadi Haqil.

Groundwater is stored in four main types of aquifers: karst in carbonate rocks, fissured in ophiolites, and intergranular in gravel and sand dunes. Karst aquifers of rocky slopes and intergranular aquifers of alluvial deposits are characteristic for wadis. The surface water that drains through wadis represents the main source of recharge of the intergranular aquifers in Quaternary alluvial deposits, which are composed of gravel and sand with thin interbeds of silt and clay (Rizk \& Alsharhan 2003). The karst aquifers are composed of limestone and dolomite. They are recharged by infiltration of rain and discharged through karst springs at the contact with less permeable rocks or directly into the sea.

Karst springs named Khatt and MeBreda (Fig. 1), which differ significantly in their hydrogeological characteristics, were studied in more detail during our field work. For the comparison only, the basic physical and bacteriological parameters of samples taken at the pumping station in an intergranular aquifer and in a small collector of surface water in a rocky slope of the Wadi Haqil (Fig. 1) were defined additionally.
The Khatt spring with two main outflows Khatt north and Khatt south is located $15 \mathrm{~km}$ south of the town Ras al-Khaimah at the extreme east of the gravel plains at the foot hills of the Musandam Mountains. The gravel aquifer in the plain overlies very poorly permeable Cretaceous marls and shales with variable admixtures mixtures of coarse detrital debris of chert, basic igneous rocks, and limestone. The karst recharge area of the spring is composed of Jurassic and Cretaceous dolomitic limestone and limestone. In the period from 1979 to 2004, the average annual discharge of the Khatt north spring ranged between 1 and $60 \mathrm{~L} / \mathrm{s}$, and of the Khatt south spring between 4 and $55 \mathrm{~L} / \mathrm{s}$ (Wycisk et al. 2008). Discharge oscillations clearly reflect the precipitation intensity distribution. In dry years with low amount of rain, the discharges were significantly lower. The spring with the water temperature of approximately $39^{\circ} \mathrm{C}$ is used for balneological purposes (Fig. 2B). Additionally, the water is drained into an intricate system of lined channels and falajs to support a substantial cultivation of date palms or other crops. 
In the MeBreda area in the rocky slope of the Wadi Shehah (a tributary to the Wadi Al Bih) a karst spring is situated at the altitude of $710 \mathrm{~m}$ a. s. 1 . The name MeBreda is used also for the spring. A group of local people built in 1925 two pools for collecting water at the point of a small permanent outflow of water through a fissure in dolomite. The location of the spring is most likely conditioned by the existence of a less permeable zone within the carbonate sequence. This enables the water storage in a small perched aquifer, which recharges a perennial spring with the discharge of several L/s. Water flowing out of the fissure is first collected in the upper pool (our local guide used it as drinking water), and then flows in the lower pool (water used by goats and for irrigation of a small plantation, see Fig. 2A).

Several small holes, which are artificially arranged as collectors of rain water, were seen in the rocky slope of the Wadi Haqil. One of them (in a form of a channel with the cross-section $25 \times 25 \mathrm{~cm}$ and the depth of $85 \mathrm{~cm}$; Fig. 2C) was partly filled with water in the time of our visit. Stored water is probably used by herds and goats as drinking water. In the nearby pumping station (Fig. 2D), the groundwater is pumped from a gravel aquifer and used for irrigation of agricultural land, mostly for cultivation of date palms.

\section{MEASUREMENT OF PHYSICAL AND CHEMICAL PARAMETERS}

Temperature (T) and electrical conductivity (EC) were measured in situ with a WTW MultiLine P4 conductometer and $\mathrm{pH}$ with the use of $\mathrm{pH}$-indicator strips (EMD, Germany). At the Khatt and MeBreda springs the water samples $(0.5 \mathrm{~L})$ were taken and later analyzed in the chemical laboratory of the Karst Research Institute in Postojna. Carbonate, calcium, and magnesium contents were determined using the titrimetric method, of chlorides using the standard methods with mercury nitrate, of sulfates using the standard turbidimetric method, of ophosphates using the method with tin chloride (Clesceri et al. 1998), and of nitrate using a method employing sodium salicylate.

Two indexes (Lee \& Song 2007), which are often used for the assessment of the salt water intrusion, were calculated. The Revelle index (Revelle 1941) is based on the ionic ratio $\mathrm{Cl}^{-} /\left(\mathrm{CO}_{3}^{2-}+\mathrm{HCO}_{3}^{-}\right)$in meq/L. The values below 0.5 indicate no influence of salt water, the values between 0.5 and 6.6 a moderate influence, and the values higher than 6.6 are characteristic for waters affected by salinization. The ratio $\mathrm{SO}_{4}^{2-} / \mathrm{Cl}^{-}$of sea water is approximately 0.1 .

\section{ASSESSMENT OF BACTERIOLOGICAL INDICATORS}

Drinking water in arid areas is of great concern. Because of its scarcity, its quality for human consumption is of even higher importance. For the assessment of water quality several microbiological parameters are used by the International Organization for Standardization (ISO) what is covered in the section "Water quality ICS 13.060": colony count of culturable microorganisms, sulfide-reducing anaerobes (clostridia), intestinal enterococci, Escherichia coli, coliforms and thermotolerant coliform bacteria, bacteriophages, Legionella, Cryptosporidium oocysts and Giardia cysts, thermotolerant Campylobacter species, and Salmonella spp. and Pseudomonas aeruginosa (www.iso.org). To assess eventual microbiological contamination in different water bodies in the UAE which are presumably used for human and/ or agricultural consumption Ridacount test plates were used (R-biopharm, Germany, www.r-biopharm.com). Ridacount test plates were already successfully applied for microbiological assessment of microbiological load in different habitats during expeditions in the karst underground (Mulec et al. 2012, Mulec et al. 2013). The ISO standards can be adopted also when using Ridacount test plates. We used the following ISO standards for drinking water quality during our expedition: the number of Escherichia coli and coliform bacteria must not exceed 0 colony-forming units (CFU) in a $100-\mathrm{mL}$ sample of water (SIST EN ISO 9308-1) and the total number of mesophilic bacteria at $37^{\circ} \mathrm{C}$ must be under $100 \mathrm{CFU}$ per mL (SIST EN ISO 6222). For quantitative microbial detection we calculated total counts of heterotrophic aerobic bacteria (Ridacount Total Aerobic Count), conventional total coliform bacteria and Escherichia coli (Ridacount $E$. coli/Coliform).

To avoid carrying microbiological samples in cool boxes and later inoculation in a lab at the sites we aseptically inoculated microbiological media with $1 \mathrm{~mL}$ of fresh water sample. Coliforms and E.coli are usually screened in a volume of $100 \mathrm{~mL}$, but due to limitation of lab equipment during field work, we applied $1 \mathrm{~mL}$ of water sample on microbiological media. After inoculation, test plates were placed in an incubator. Reading of results was carried out after 24 hours of cultivation at $37^{\circ} \mathrm{C}$ (www.r-biopharm.com) and expressed as $\mathrm{CFU} / \mathrm{mL}$ (Tab. 2).

\section{RESULTS OF THE WATER ANALYSIS}

Already the comparison of basic physical parameters shows very different types of analyzed waters. The EC value of groundwater from the gravel aquifer is very high due to salinization. In the small collector of rain water 
Tab. 2: Sampling sites with examined physical and bacteriological parameters (nd - no data).

\begin{tabular}{|c|c|c|c|c|c|c|c|c|}
\hline $\begin{array}{l}\text { Date } \\
(d d / \mathrm{mm} / \mathrm{yy})\end{array}$ & Site & Water use & $\begin{array}{l}\text { Ecosystem } \\
\text { type }\end{array}$ & $\begin{array}{c}\text { Temperature } \\
T\left({ }^{\circ} \mathrm{C}\right)\end{array}$ & $p H$ & $\begin{array}{l}\text { Conductivity } \\
S E C(\mu S / \mathrm{cm})\end{array}$ & $\begin{array}{c}\text { Total } \\
\text { bacteria } \\
\text { (CFU/mL) }\end{array}$ & $\begin{array}{l}\text { E.coli/ } \\
\text { Coliforms } \\
\text { (CFU/mL) }\end{array}$ \\
\hline $24 / 01 / 11$ & $\begin{array}{l}\text { Wadi Haqil, collected } \\
\text { rainwater }\end{array}$ & livestock & lentic & 19.8 & 6.5 & 1,710 & 24 & $3 / 3$ \\
\hline 24/01/11 & $\begin{array}{l}\text { Wadi Haqil, water } \\
\text { pumped from a gravel } \\
\text { aquifer }\end{array}$ & agriculture & lotic & 30.0 & 5.0 & 14,400 & 0 & $0 / 0$ \\
\hline $27 / 01 / 11$ & $\begin{array}{l}\text { Wadi Shehah, } \\
\text { MeBreda spring }\end{array}$ & drinking & lotic & nd & nd & nd & 28 & $0 / 4$ \\
\hline $27 / 01 / 11$ & $\begin{array}{l}\text { Wadi Shehah, } \\
\text { MeBreda spring, upper } \\
\text { pool }\end{array}$ & $\begin{array}{l}\text { agriculture, } \\
\text { drinking }\end{array}$ & lentic & nd & 7.0 & 738 & 375 & $0 / 64$ \\
\hline $27 / 01 / 11$ & $\begin{array}{l}\text { Wadi Shehah, } \\
\text { MeBreda spring, lower } \\
\text { pool }\end{array}$ & agriculture & lentic & nd & nd & nd & 1,271 & $6 / 553$ \\
\hline $25 / 01 / 11$ & Spa Khatt, spring & balneology & lotic & 38.5 & 7.5 & 2,340 & 22 & $0 / 2$ \\
\hline
\end{tabular}

Tab. 3: Chemical parameters of water samples taken in the MeBreda and Khatt springs.

\begin{tabular}{l|c|c|c|c|c|c|c|c|c}
\hline Spring & $\begin{array}{c}\text { Carbonates } \\
(\mathrm{meq} / \mathrm{L})\end{array}$ & $\begin{array}{c}\mathrm{Ca}^{2+} \\
(\mathrm{meq} / \mathrm{L})\end{array}$ & $\begin{array}{c}\mathrm{Mg}^{2+} \\
(\mathrm{meq} / \mathrm{L})\end{array}$ & $\begin{array}{c}\mathrm{Cl}^{-} \\
(\mathrm{mg} / \mathrm{L})\end{array}$ & $\begin{array}{c}\mathrm{NO}_{3}^{-} \\
(\mathrm{mg} / \mathrm{L})\end{array}$ & $\begin{array}{c}\mathrm{SO}_{4}^{2-} \\
(\mathrm{mg} / \mathrm{L})\end{array}$ & $\begin{array}{c}\mathrm{PO}_{4}^{3-} \\
(\mathrm{mg} / \mathrm{L})\end{array}$ & $\begin{array}{c}\text { Revelle } \\
\text { index }\end{array}$ & $\begin{array}{c}\mathrm{SO}_{4}^{2-} / \mathrm{Cl}^{-} \\
(-)\end{array}$ \\
\hline MeBreda & 3.3 & 3.1 & 2.0 & 64 & 19.4 & 93 & $<0.01$ & 0.5 & 1.1 \\
\hline Khatt & 3.9 & 4.8 & 2.1 & 595 & 8.1 & 165 & $<0.01$ & 4.3 & 0.2 \\
\hline
\end{tabular}

in the rocky slope of the Wadi Haqil stagnant water was sampled, which has been altered by some additional influences.

The results show that although both, the MeBreda and Khatt springs, are recharged from karst aquifers, they differ significantly. The anions arranged according to their decreasing concentrations are $\mathrm{HCO}_{3}^{-}>\mathrm{SO}_{4}^{2-}>$ $\mathrm{Cl}^{-}>\mathrm{NO}_{3}^{-}$in the MeBreda spring and $\mathrm{HCO}_{3}^{-}>\mathrm{Cl}^{-}>$ $\mathrm{SO}_{4}^{2-}>\mathrm{NO}_{3}^{-}$in the Khatt spring. The springs have significantly different T, EC, and concentrations of anions. Relatively low EC, the chemical composition of water, and the ratio $\mathrm{Ca}^{2+} / \mathrm{Mg}^{2+}=1.6$ in the MeBreda spring indicate an outflow from a carbonate aquifer with a larger share of dolomite. Increased concentrations of nitrates are due to grazing goats around the spring.

According to its high temperature of $38.5^{\circ} \mathrm{C}$ the Khatt spring can be characterized as a thermal spring with deep groundwater circulation. For other springs in the northern part of the UAE the temperatures of springs range from $25^{\circ} \mathrm{C}$ to $32^{\circ} \mathrm{C}$ (Wycisk et al. 2008). The chemical composition of water reflects recharge from a karst aquifer composed of dolomite and limestone, and higher value of EC, higher concentrations of chlorides and sulfates, and the values of the Revelle index and the ratio $\mathrm{SO}_{4}^{2-} / \mathrm{Cl}^{-}$indicate a moderate influence of salinization. Probably the infiltrated rain water is mixed with more saline and mineralized water from greater depths.

Viable microbes on Ridacount test plates were retrieved from all sampling sites except from water pumped from the underground which had high conductivity. Surprisingly, the traditionally collected rainwater in natural crack had low number of total bacterial count; however detected $E$. coli indicated probable fecal contamination of water from pasturing goats. Water taken directly from the orifice of karst spring in Wadi Al Bih had the lowest bacterial counts in all three bacterial indicator groups (total bacteria, coliform bacteria, E. coli) compared to downstream samples. Water captured in pools had higher bacterial counts which can be free used only for agriculture as colonies of E.coli were already detected in one $\mathrm{mL}$ of a sample.

Considering two ISO standards SIST EN ISO 9308-1 (coliforms and E. coli) and SIST EN ISO 6222 (total bacteria) none of the water from any of the tested sites matched the ISO criteria for direct human consumption. 


\section{CHARACTERISTICS OF CAVES AND CAVE SEDIMENTS}

Only few references report on caves and karst phenomena in the UAE (Jeannin 1992, Waltham \& Jeannin 1998, Fogg et al. 2002). Our primary target region were mountainous in the NE part of the Ras Al-Khamaih Emirate. Close to the border with Oman, on the slopes of Mount Al-Jeer, several cave entrances were reported by local people. All these entrances came out to be small cavities narrowing from the entrance inwards and ending after a few meters. They have developed in thin-layered limestone in places alternating with layers of dolomite (Fig. 3); the bads are inclined at an average of $50^{\circ}$ and are folded and broken. Faults occurred along numerous bedding planes due to tilting and folding, resulting in faster karstification in these sections. Karstified areas occur at contacts between individual strata especially along moved bedding planes. The depth of karstified contacts between individual beds is only about five meters, and the average diameter of cave entrances is about one square meter. The cave floors are covered with autogenic breakdown material, light grey clay, bones, and larger plant seeds. The surface of the rock is finely and shallowly corroded exhibiting many solution pans with outflow channels.

Several more caves and areas with caves were reported to us by locals as information on our work was well spread.

North East from Ras Al-Khaimah a large number of small cavities and that characterize the slopes at the mouth of Wadi Haqil (Fig. 4A) where a quick look at the hill resembles to a block of limestone characterized by spongework porosity. The rocks in the vicinity of the cave in Wadi Haqil were studied in detail. The average thickness of the strata is $30 \mathrm{~cm}$ and their dip $80 / 85$. The selected strata lie between two stronger fault zones that are parallel to the stratification. The karstified area is limited to a segment of strata between stronger tec- tonically substantially broken zones of rock more than ten meters thick. However exploration revealed that cavities are mainly unlinked. The only cave longer than $10 \mathrm{~m}$ is shown on Fig. 4A. It is a simple uniform (blind!) channel with oval cross-section. Cavities contain a substantial amount of clastic sediment. Some are fully and some partially filled with yellow clastic sediments. Fine grained yellow sediment is mostly cemented and includes well visible gypsum crystals. Below and in between the clastic sediments, crusts with calcite crystals and layered flowstone were observed. Samples of clastic sediments from 4 different locations on the hill were taken. Three of them were part of so called Profile 1 (Fig. 4C, Tab.4): SNo1 grey sediment from bottom of the profile, SNo 2 laminated sediment above flowstone, and SNo 3 red sediment below flowstone. On top of the hill was taken sample SNo 4 of yellow sediment from already unroofed channel. From the middle of the hill, from profile of sediment in the wall, was taken sample SNo 5 of grey sediment with gypsum crystals. From Meander Cave sample SNo6 was taken from the brown sediment profile at the end of the cave. In caves in Wadi Haqiul mouse-tailed bats (Rhinopomatidae) were observed which belong to the species Rhinopoma cystops.

All samples were analyzed by $\mathrm{x}$-ray diffraction method in the Laboratory of Physical Methods at Institute of Geology CAS in Prague. All samples contain quartz, gypsum and kaolinite, almost all of them also calcite, palygorskite, smectite and illite (Tab. 4). In sample SNo5 was in traces present also K-feldspar and in SNo1 and 2 also chlorite. Calcite and gypsum represent precipitates in the cave /crusts and/or cements) and other minerals were brought to the cave most probably by water from eroded rocks and/or soils from wadi catchment area. Palygorskite and smectite often occur in des-

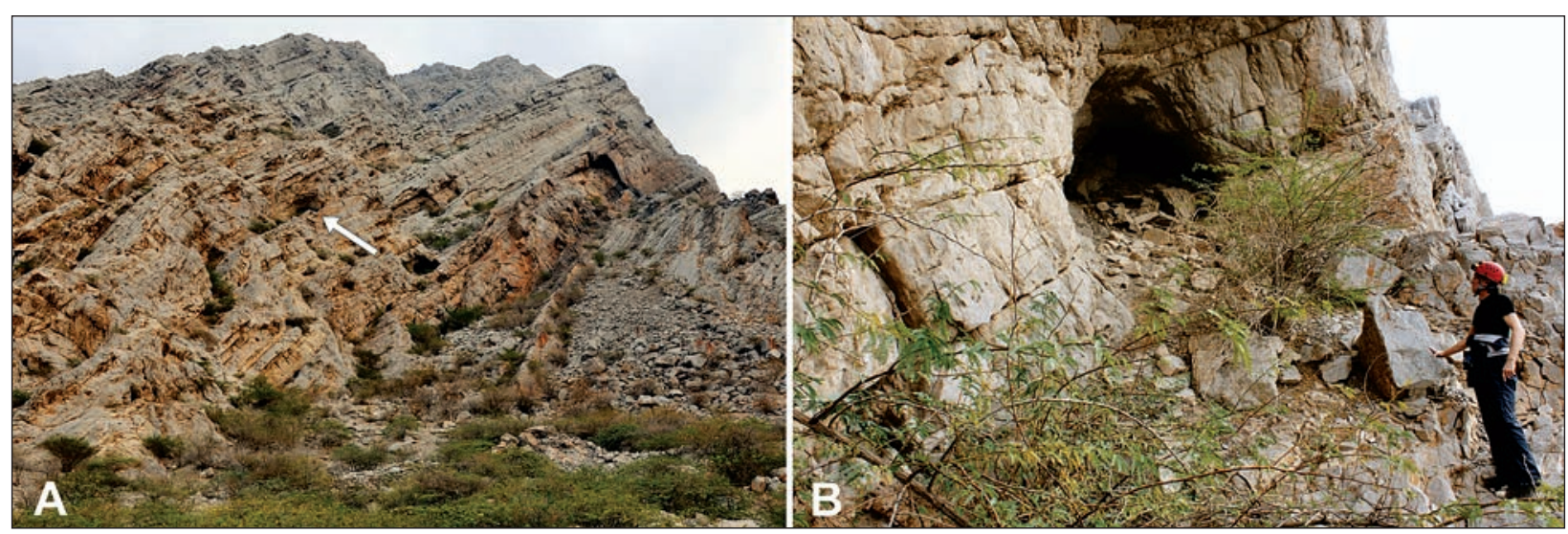

Fig. 3: a) Numerous voids developed along bedding planes of the rocky slope in the Al Jeer Mount An arrow indicates the entrance shown on Fig. 3B. b) A closer look to one of the entrances, which appeared to be a small chamber. 


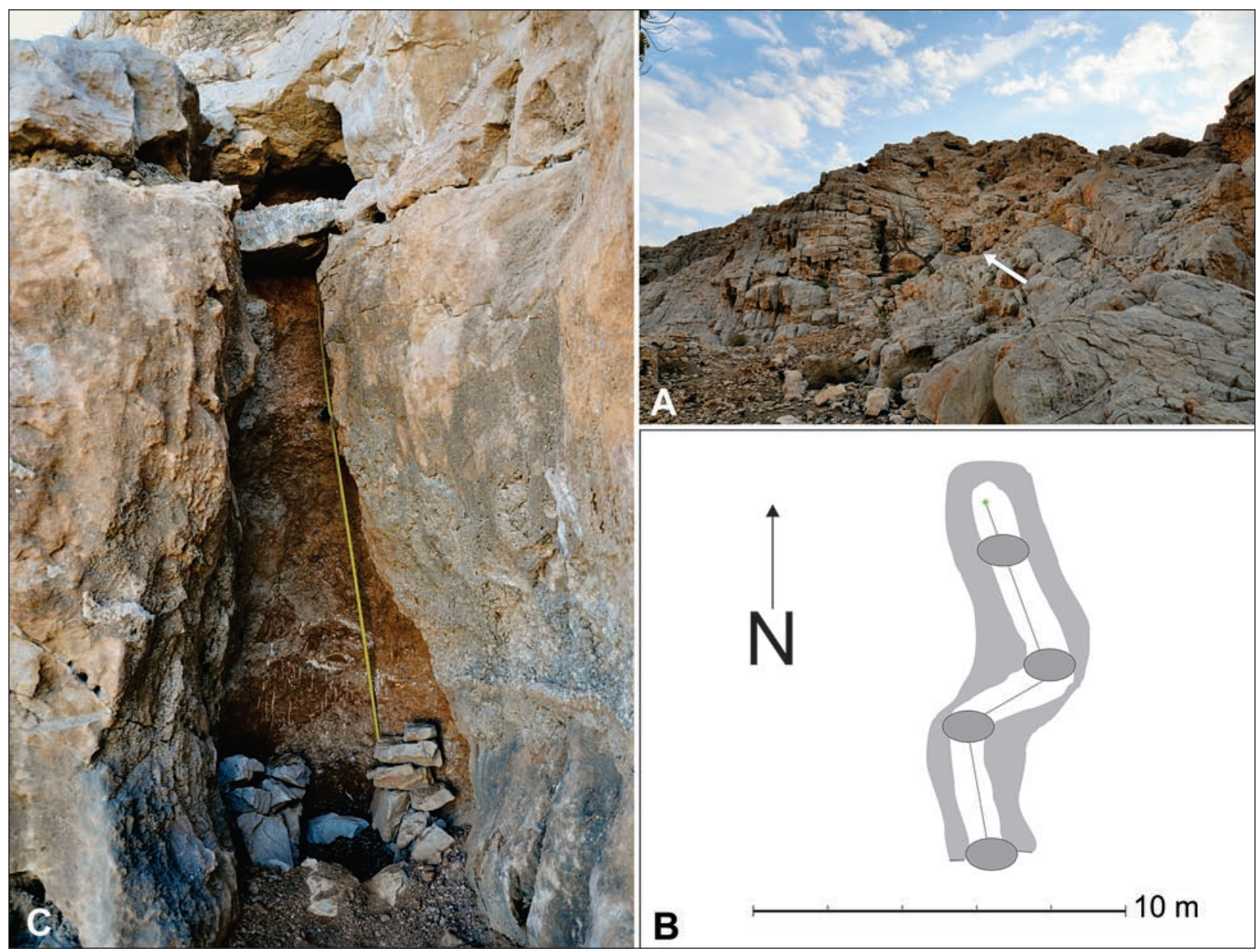

Fig. 4: a) Detail of the right bank of Wadi Haqil close to its entrance. An arrow indicates the entrance to the cave shown in a plan view on Fig. 4B. b) Plan view of the longest l cave found on the slope above Wadi Haqil. c) Profile 1, where sediments SNo1-SNo5 were sampled.

Tab. 4: Mineral identification in bulk samples.

\begin{tabular}{l|l}
\hline $\begin{array}{l}\text { Sediment } \\
\text { sample }\end{array}$ & Mineral composition \\
\hline SNo 1 & $\begin{array}{l}\text { gypsum, quartz, calcite, palygorskite, kaolinite, } \\
\text { smectite }\end{array}$ \\
\hline SNo2 & $\begin{array}{l}\text { calcite, quartz, kaolinite, smectite, illite, } \\
\text { palygorskite, gypsum }\end{array}$ \\
\hline SNo3 & $\begin{array}{l}\text { quartz, calcite, gypsum, smectite, kaolinite, } \\
\text { palygorskite }\end{array}$ \\
\hline SNo4 & calcite, quartz, gypsum, kaolinite, palygorskite \\
\hline SNo5 & $\begin{array}{l}\text { gypsum, calcite, quartz, palygorskite, smectite, } \\
\text { kaolinite, illite }\end{array}$ \\
\hline SNo6 & quartz, gypsum, kaolinite, smectite, illite \\
\hline
\end{tabular}

ert types of soils or sediments connected with arid and semi-arid depositional settings (Murray et al. 2011).

In the wider area of the Wadi Tawiyeen the rocks were thinly stratified, in places thinly laminated laterally. The strata are in average $10 \mathrm{~cm}$ thick and with dip of 160/25. Along Wadi Tawiyeen many cavities can be ob-

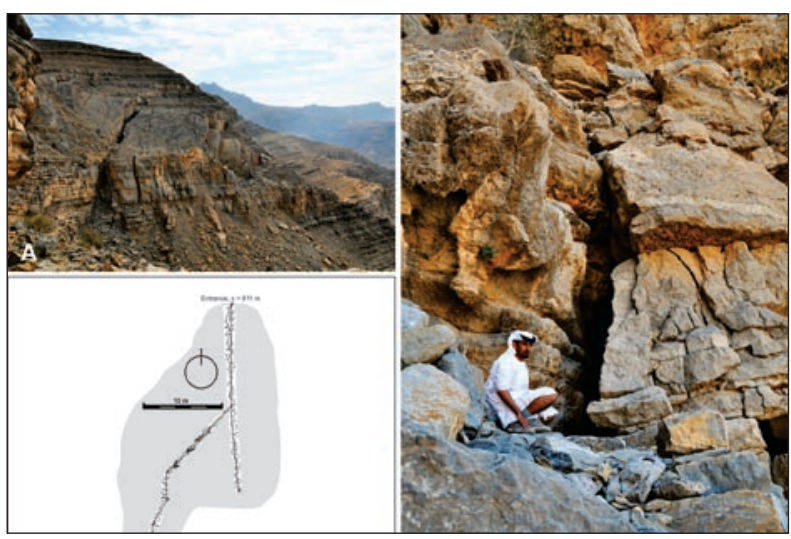

Fig. 5: Notch at the foot of Wadi Tawiyeen.

served in several places. One of them is in the foot of the wadi, and probably represents a notch (Fig. 5). The cave floor is full of gravel, sand and clay. Sample SNo7 of fluvial fine-grained orange sand was taken here. Quartz prevailed in the sample with the presence of calcite, al- 

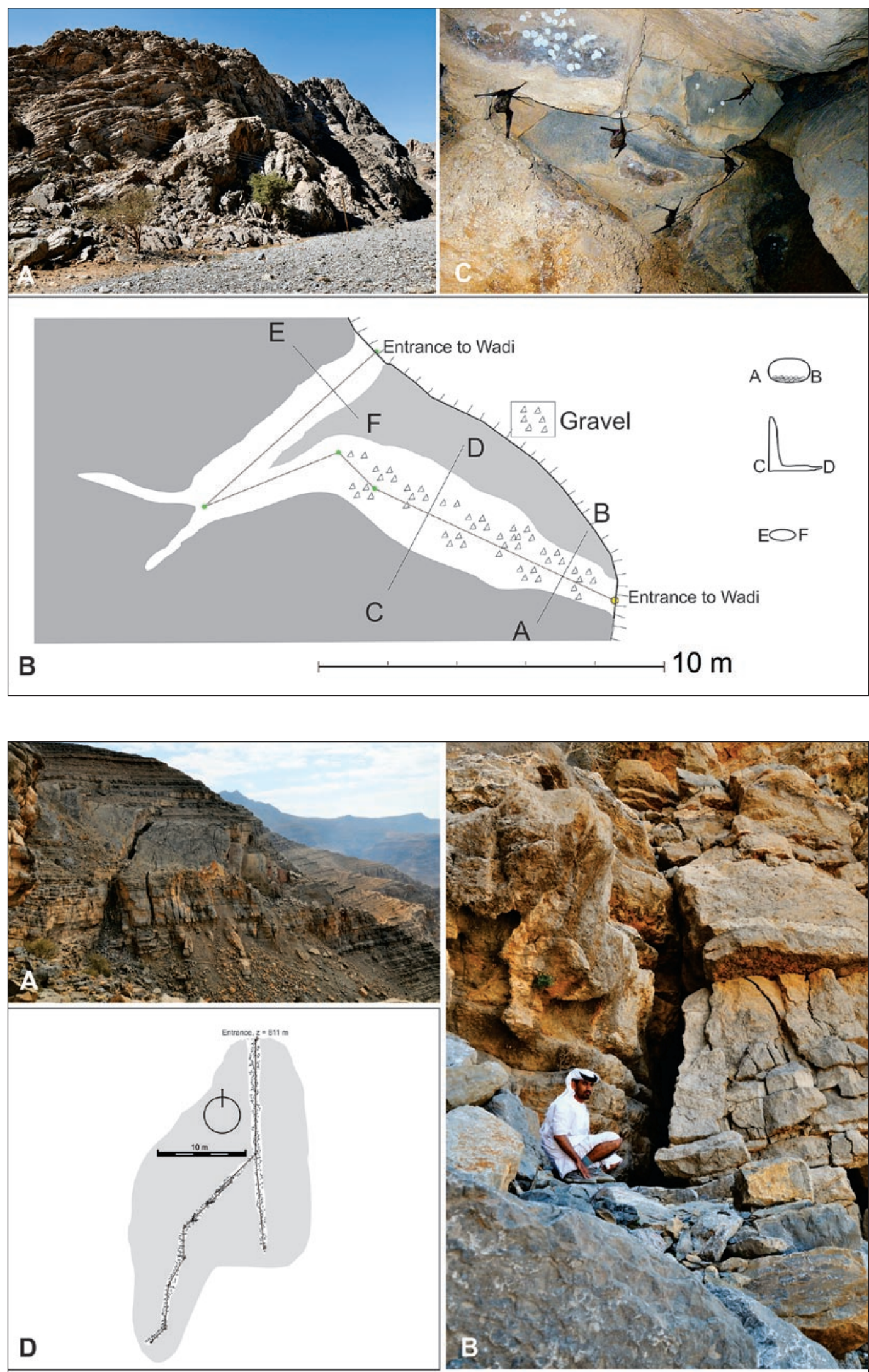

Fig. 6:

a) Detail of the right bank of the middle part of Wadi Tawiyeen with entrance to the cave about $30 \mathrm{~m}$ above the bottom.

b) Cave plan. c) Mouse-tailed bats (Rhinopomatidae).

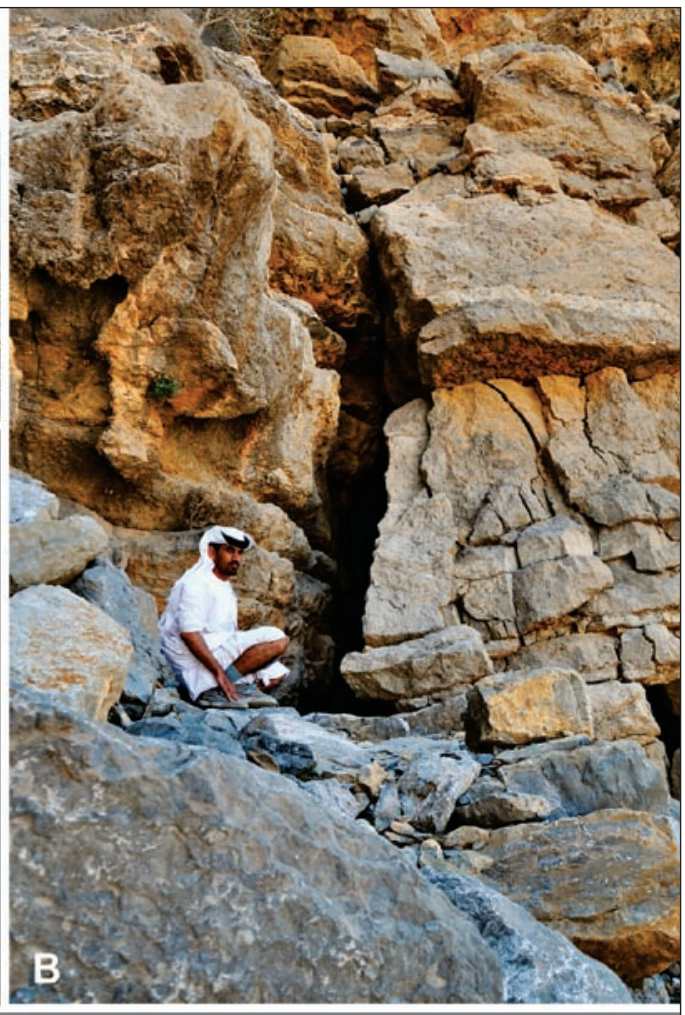

Fig. 7:

a) Rocky slope above Jebel Al Khab with a cave entrance marked by an arrow. b) Rectangular shaped entrance. c) Plan of the cave. 


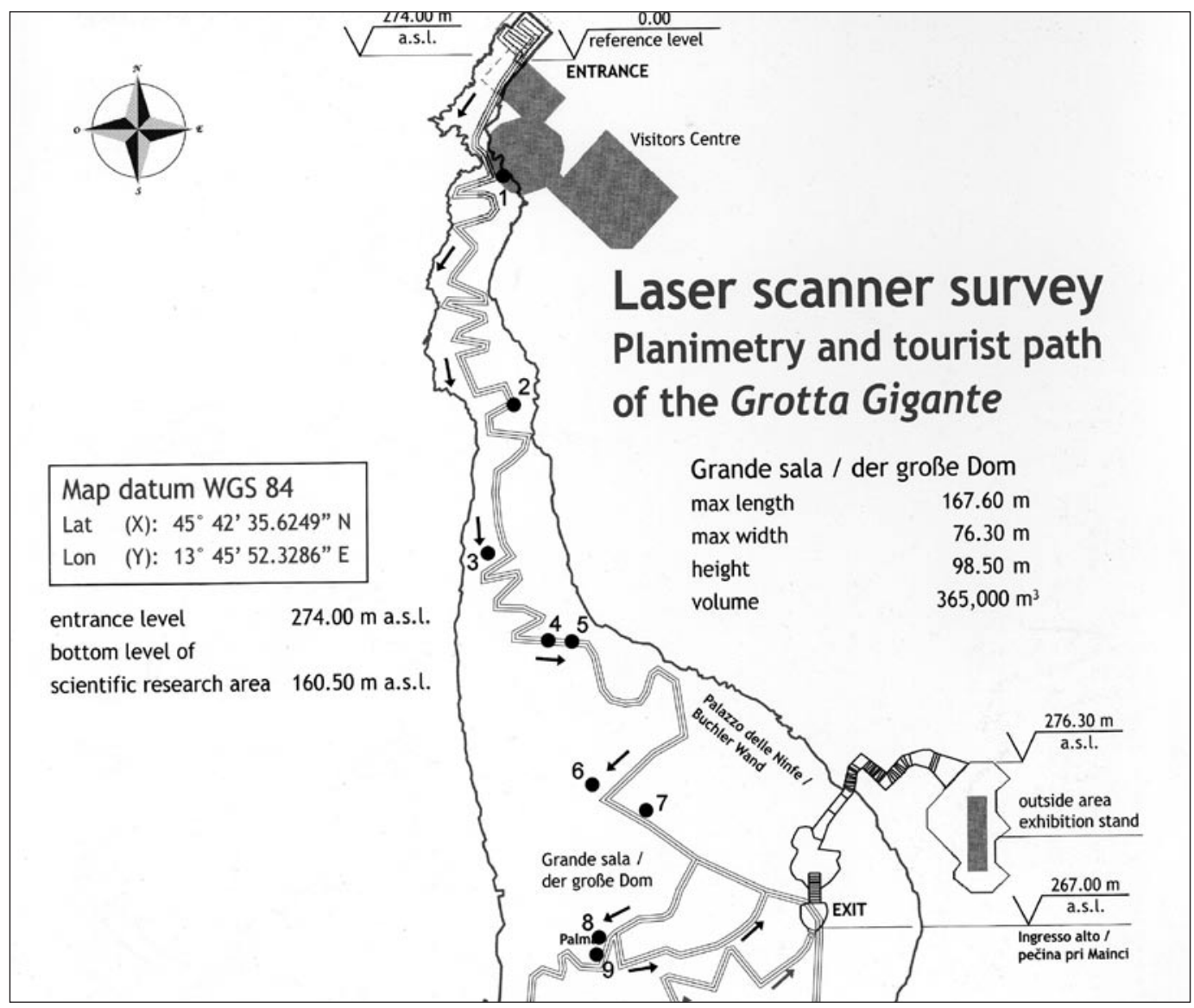

Fig. 8:

a) The slopes

above Wadi Maai

with numerous

voids;

b) An rntrance to the largest cave.

c) A plan view

(left) and

extended eleva-

tion (right)

of the cave.
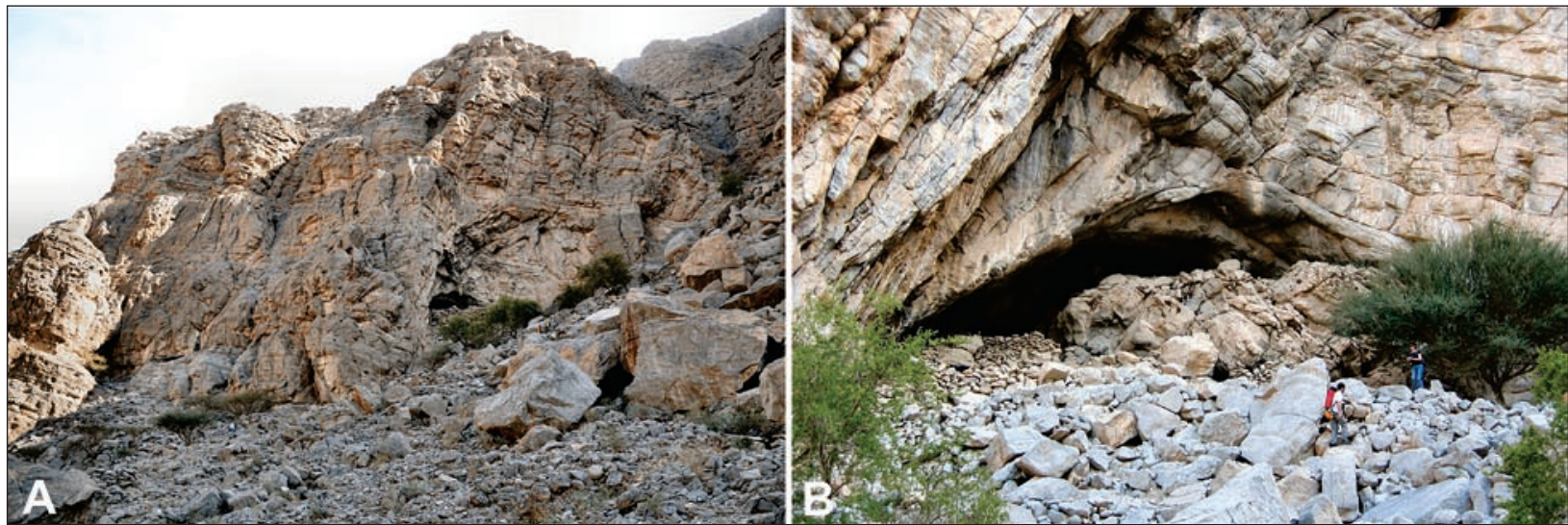

Fig. 9: a) Slopes above wadi Shie Haft with two entrances. b) One of the entrances where the potential continuation is completely filled with blocks and loam.

bite, orthoclase and rutile. Few kilometers upstream, a cave shown on Figure 6 was surveyed $\left(25^{\circ} 34^{\prime} \mathrm{N}\right.$, $\left.56^{\circ} 07^{\prime} \mathrm{E}\right)$. The entrance is $30 \mathrm{~m}$ above the bottom of the wadi. The main channel changes from an oval shaped entrance to an L-shaped channel with increasingly distinct ceiling channel. The channel ends with two blind branches and a rounded conduit leading to a second entrance in the wall of the wadi.
In the area of Jebel Al Khab, the upper part of the wadi widens. About $100 \mathrm{~m}$ above the surface of the most extensive plain, a cave entrance (Fig. 7A) can be seen at the side of a tributary gorge $\left(25^{\circ} 46^{\prime} 36^{\prime \prime} \mathrm{N}, 56^{\circ} 08^{\prime} 29^{\prime \prime} \mathrm{E}\right)$. The cave is formed in $15 \mathrm{~cm}$ thick layers with a dip of 190/15. In upper and lower part of the profile the layers are thick, up to one meter. They are tectonically crushed and tend to disintegrate intensely due to their smaller thickness at 

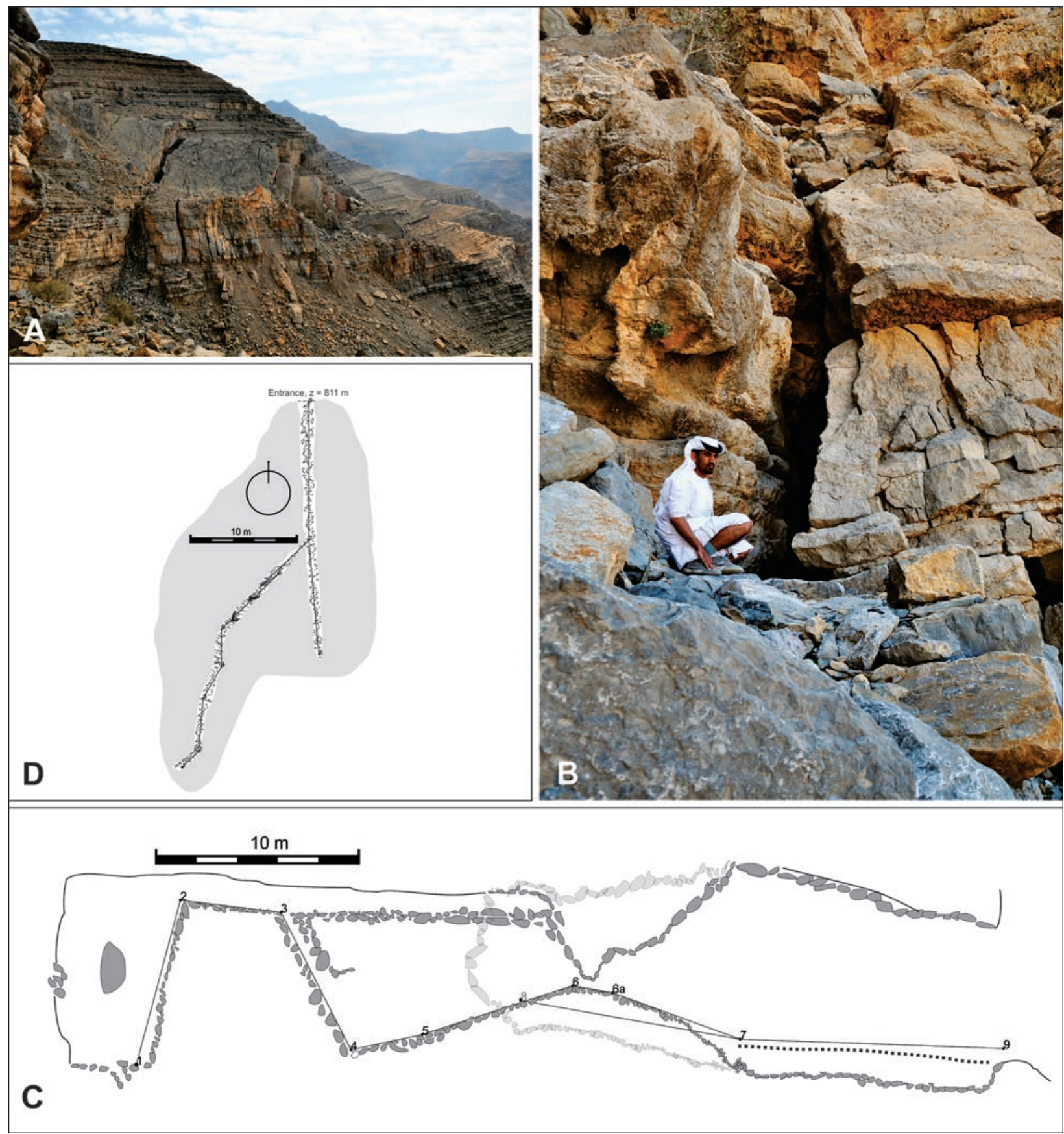

Fig. 10: a) Slopes on MeBreda above Wadi Shehah. Due to the gravity slide a large block has separated resulting in formation of numerous tensile fractures crevasses and breakdowns. The arrow indicates the position of the entrance. $b$ ) A closer look to the entrance. c) Extended elevation of the cave; d) Plan of the cave.

the edge of the wall. The entrance is rectangular shaped, $2 \times 3 \mathrm{~m}$ in size (Fig.7B). It continues with about $10 \mathrm{~m}$ long channel with well-expressed ceiling channels and side pockets (Fig. 7C). The channel branches into several smaller channels, one of them exiting at the side wall. Fine-grained sediments with high organic content (including fungi) cover the floor.
About $4 \mathrm{~km}$ east, numerous voids and several small caves were observed along the slopes of Wadi Maai (Fig. 8A). Strongly recrystallized limstones are folded and tectonically heavily broken in the vicinity of the karstified pockets. Dip of the beds is $0 / 20$ in the area of the cave. The biggest cave (Fig. 8C) $\left(25^{\circ} 36^{\prime} 58^{\prime \prime} \mathrm{N}, 56^{\circ} 06^{\prime} 13^{\prime \prime} \mathrm{E}\right)$ is about $10 \mathrm{~m}$ above wadi's bottom. The cave developed 
at the contact of non-dolomitized and dolomitized rock. The entrance ( $10 \mathrm{~m}$ wide, 2-4 meters high) continues with a large channel with side niches, pockets and several leads. One of these extents vertically and continues for several meters. Other passage, leading from where the entrance chamber ends, up to another chamber with several blind sub vertical channels. Clays mixed by breakdown gravel cover the floor.

In Wadi Al Bih two tributary wadis were prospected for eventual caves. In Wadi Shie Haft, relatively large cave entrance is located on the wadi slope. A possible continuation was blocked for further exploration by a large accumulation of breakdown material and clay (Fig. 9).
A cave (825 $\mathrm{m}$ a. s. l) very different in comparison with others is positioned close to the top of MeBreda above Wadi Shehah (tributary to Wadi Al Bih). In the wider vicinity, the heavily tectonically broken and recrystallized rock has a general dip of $300 / 80$. The cave follows a set of vertical fractures disrupted by active breakdowns with absolutely no dissolutional features. A broader perspective (Fig. 10A) reveals that the cave is a tectonic cave. It is part of a (dominantly tensile) fracture system that formed as a consequence of a gravity slide. The sliding is active along a discontinuity which dips slightly towards the valley; a large block of stone of several hundred million cubic meters in size is in the process of breaking off. We observed constant mass movements of rock and rock fragments in the studied fissure/cave.

\section{ROCK RELIEF}

Characteristic rock relief dissects the circumference of the special caves forming in the walls of the wadis that were studied comprehensively for the first time. The slopes of the wadis are often dissected by large recesses, relatively rare subsoil forms, and karren with microrills and rain flutes. Karren-like rock surface also occurs between wadis, and rock forms are found on rocks that have broken off from the slopes as well as on and in the sediments covering the bottoms of the wadis. More extensive karren are found on the tops of the mountains. The rocky riverbeds of wadis were shaped by rapid water currents and corrosion at the contact with sediment. Rock forms are an important trace of the formation and development of caves and karst surfaces.

\section{ROCK RELIEF OF CAVES}

Caves in wadis are located just above the sediment level and are therefore periodically flooded and dry at various levels above it. They also share similar rock relief. Ceiling pockets are found on the ceilings of niches that developed at the contacts of passages and at their sharp bends in areas of emphasized swirling of water. As a rule, their diameters do not exceed one meter but they are usually deeper, with a 1:3 ratio, and wider in the upper part. In places, pockets are also found on walls, but their lower parts are flat and their upper parts are vaulted (Fig. 11A). The lower parts were frequently covered by sediment that protected the rock from dissolving and erosion and therefore grew upwards and sideways. The walls of passages are smooth and rounded. The mechanical erosive action of water currents carrying material appears to play an important role in their formation. The ceilings of pas- sages are usually characterised by above-sediment channels (Fig. 11B) that along with the paragenetically raised cross sections of passages indicate the frequent filling of caves with sediments and the flow of smaller quantities of water above them. The largest reach depth of one meter, the consequence of the relatively long-term formation of caves of this kind and their filling with sediment. Alongsediment wall notches, up to one meter deep, indicate periodic partial filling of the caves and a long lasting sediment level in the cave. Along-sediment rock forms are the trace of relatively frequent filling of wadis with sediment and its removal.

\section{ROCK RELIEF OF WADI RIVERBEDS}

Potholes, sub-sediment pockets, and sub-sediment channels are the dominant forms found in rocky riverbeds and on rocks in smaller wadis. In places, potholes located at the edge of the rock grew into tubes one meter or more in diameter. Tubes (Fig. 11C) one or two meters in length and from a few tens of centimeters to one meter or more in diameter are also found in the walls. They could be seen as the beginning of characteristic caves. Only the lowest parts of the riverbed are usually smoothed by erosion, while sub-sediment pockets and sub-sediment flutes (Fig. 11D) are found higher up, the traces of a periodically flooded riverbed.

\section{ROCK FORMS ON WADI SLOPES, ON ROCKS AND IN THE SEDIMENT, AND ON MOUNTAIN TOPS}

Large pockets (Fig. 11E) on the walls of the wadis are one of their most characteristic forms. In places they 
dissect the majority of rocky wadi slopes, elsewhere their larger part, or only individual sections, in short, anywhere they have not been transformed due to the decomposition of the rock or shaped by rapid water flows in the river beds. The pockets are found on vertical, inclined, and overhanging surfaces. Their diameter and depth are measured in meters. Relative to their size, the openings are either shallow or deep. Along fissures and bedding planes their cross sections are most frequently elliptical. Above-horizontal or gently sloping bedding planes they are as a rule developed only in the stratum of the rock above them. They are either single or composite. Some of the pockets display dominant characteristic forms indicating their formation along sediment. As a rule, the lower sections of their circumferences are more or less horizontal while the upper parts are semi-circular or narrow towards the top (Fig. 11F) . The bottom sections of the pockets are often wide. On the tops or on the walls there are straight or winding channels that most probably formed due to the water flowing at the contact with sediment. The circumference of their upper parts, especially those that widen upwards, is dissected by smaller bell-shaped ceiling pockets that formed when the water flowed through a fissure into a pocket filled with the sediment. In most cases, the edge of the opening of large pockets is thin, measuring only a few centimeters. Behind it the pocket widens. Their bottom sections are usually open. Large pockets are dominated by the paragenetic formation of ceiling pockets in the locally flooded zone. The water constantly fills them with sediment that makes them widen and grow upward (Slabe 1995). With the lowering of the water level that permeates the sediment, the water flows downward along the walls, often opening the pockets in the process. This indicates that when the pockets are denuded the rock weathers at a faster rate and are therefore shaped or transformed by the "cavernous weathering process" (Goudie 2009). In shallow circular pockets with a distinctive thin outer edge, this process, accelerated by various salts present in the rock, wind, and microclimatic characteristics in the pocket (Goudie 2009), could be the dominant one. The rock surface of the majority pockets displays fine weathering. Is this how the large or deep pockets formed? Does this mean the faster weathering of the rock in the upper part and the deposit of weathered debris in the bottom part resulting in the asymmetrical shape of the pockets? Can we speak about tafoni in all such cases? In some pockets, a honeycomb of tiny holes developed on the upper edge that could be the consequence of the rapid disintegration of the rock due to "evaporite cooling of the saline solution in the cavity" (Rodríguez-Navarro et. al 1999 in Goudie 2009) or they could have developed at the contact with sediment as in caves. In the wadi Haqil, pockets are found at the end of smaller caves filled with sediment or they reach the size of smaller caves themselves. The water often flowed along a bedding plane into the rock and paragenetically transformed it. In places, the thin edges of pockets are extended by flowstone that in all probability was deposited on the contents of the pocket; today, however, it is dissolving and decomposing. All the walls in the wadi caves display clear traces of long-term filling with sediment. Hunt (1996) and Goudie (2009) explains such pockets on Malta as originally subsoil in character and later transformed by "subaerial weathering processes." At this stage we can conclude that these are mostly composite rock forms with traces of frequent dominance by one of the factors of their formation, along-sediment factors being the most distinctive. These are important questions, because these forms are characteristic of this karst and give it a distinctive and unique appearance.

Rocks in the sediment also display sub-sediment channels up to one meter in diameter. The upper parts of subsoil channels are open or semi-pocket-like at the sediment level. They are shaped by water that flows from the surface of the sediment and percolates downwards along the contact with the rock. There are also s-hallow along-sediment notches at the sediment level.

Subsoil cups and subsoil channels developed on rock that was covered by soil or sediment to a large degree or only in places (Slabe \& Liu 2009). On horizontal or inclined surfaces denuded pockets are transformed into shallow solution pans. Networks of smaller subsoil channels developed into belts of shallow and elongated notches that were covered for a longer time by sediment or soil in the direction of inclination of the surface. Smaller and winding channels developed when water flowed from higher lying soil or sediment.

On bare rock there are microrills (Figs. 11G, H) that are mainly characteristic of relatively recently denuded rock surfaces and as a rule are the first and most frequent rock forms on such surfaces. They are found on the slightly inclined surfaces of wadi slopes, on the rocks on their bottoms, and on the karren between wadis. They are composed of small cups linked in a linear fashion (Gómez-Pujol \& Fornos 2009). They are carved by thin film of capillary-guided moisture that crumbles the rock. The film of water or rain then removes pieces of the rock (Gómez-Pujol \& Fornos 2009, 83). On the slopes of the wadis or on the rocks in them, the microrills measure several decimeters in length. They are relatively straight and distinctly oriented downward but not all of them are linear. Some meander slightly on the typical rock surface, which most often has previously undergone subsoil transformation. On the walls of the riverbeds of smaller wadis, one meter or more above the 


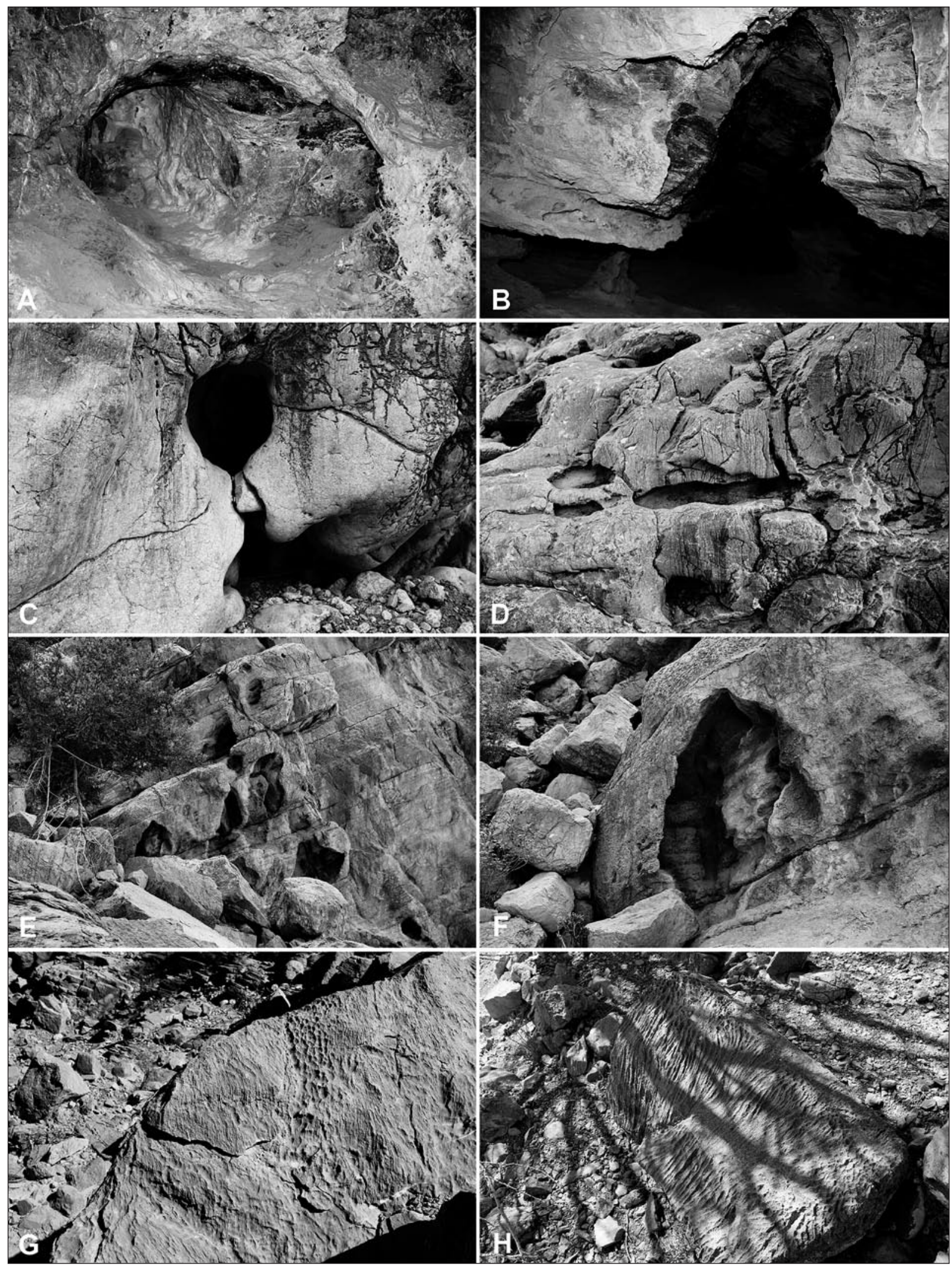

Fig. 11: Rock forms; a) Ceiling pocket. b) Above the sediment channel. c) Tubes in wadi beds. d) Sub sediment flutes. e,f) Large pockets on the wadi slopes. g,h) Microrills. 
bottom where the lower walls have been smoothed by erosion, the microrills are woven in a dense network. They are periodically flooded by water that appears to deposit thin-grained sediment in them. Cups often form on horizontal or gently sloping tops of rocks, and microrills are found on inclined surfaces below them. These are rain pits. Some appear to be of subsoil origin. Larger rocks display networks of rain flutes and rain pits
(Fig. 11H) as well as microrills on the surface between them, that is, on the sections of the rock that were covered by sediment or soil for a longer period. Scallops are found on overhanging walls and are the traces of water creeping over a larger surface. Although rain flutes are relatively rare, individual rocks can be completely covered with them. Channels where water flows from rain flutes are found in notches.

\section{DISCUSSION}

Several areas in Ras Al-Khaimah emirate on the Musandam Peninsula were surveyed in aspect of water quality and finding of new caves. At all described locations physical and chemical parameters were measured and basic bacteriological analyses were done, because drinking water in arid areas is of great concern. Already the comparison of basic physical parameters shows very different types of analyzed waters which indicate the local influences of geology, climate and population.

During exploration we found several small caves, but no big cave was found. In an area, with an average annual precipitation only slightly above one hundred millimeters and small infiltration ratio, karst surface forms, caves and springs are rare.

Detailed geological studies have shown that the significant factors for the karstification and the growth of the caves in the studied wadis were like everywhere: bedding planes and slips along them, older tectonically broken zones in the carbonate rocks, occurrence of large concentrations of calcite, contacts between dolomitized and non-dolomitized rocks, and last but not least, recent fissures and faults.

The described caves along with several smaller ones show some common characteristics that could point to their origin. The passages are generally round with well expressed ceiling channels, wall and ceiling pockets, and dead ends. There are no obvious flow paths along which caves developed. In some areas the vuggy porosity resembles that found in caves of hypogene origin. However, we did not observe any other typical indicators of hypogene origin. The dimensions of passages decrease from the entrance toward the interior of caves. Most caves end with solid walls with no leads continuing into the massif. Scallops are rare or non-existent.

At this stage we do not have firm arguments for any mechanism behind the origin of these caves; however, some of the characteristics mentioned above indicate that the caves originated from near-surface processes. We found and studied mainly clastic sediments. Spele- othems are rare, probably due to the arid climate and the very low and diffuse infiltration from the surface. Sediment samples differ in content due to their origin in different rock. Along with fluvial cave sediments, eolian sediments and sediments of organic origin (guano, bones, seeds) are also present.

Cave rock relief and surface rock relief indicate the major significance of along-sediment and subsoil formation of the wadis and the karst between them. We can observe the development of wadis through extensive filling with sediment and rocks from the slope, the shaping of rock at the contact with sediment, and the emptying or distinct change of the sediment level. The majority of caves, including those currently located high above any sediment, were filled with sediment over a longer period. The walls on the sides of wadis commonly exhibit individual or linked cavities that resemble tafoni (Rodriguez-Navarro et al. 1999) of various sizes. Some of these, although rare, are large enough to enter.

Cave rock relief and surface rock relief indicate the major significance of along-sediment and subsoil formation of the wadis and the karst between them. We can observe the development of wadis through extensive filling with sediment and rocks from the slope, the shaping of rock at the contact with sediment, and the emptying or distinct change of the sediment level. The majority of caves, including those currently located high above any sediment, were filled with sediment over a longer period. The walls on the sides of wadis commonly exhibit individual or linked cavities that resemble tafoni of various sizes. Some of these, although rare, are large enough to enter.

The general morphology of caves can be linked to floodwater patterns (e.g., Palmer 2007). The flow patterns in bed sediments of wadis are known to be very complex. The carbonate bedrock at the side of the wadis is therefore exposed to dissolution by both superficially flowing water and water flowing within the sediments. The dissolution could occur along the sediment-bedrock 
contact resulting in cave geometry defined by the combined action of dissolution and sediment morphology. This suggests that caves could form as the wadis develop.
However, this hypothesis needs further field and theoretical verification. The lack of fluvial sediments in the caves surely raises doubts about the genesis.

\section{CONCLUSIONS}

We didn't find any big caves.

One possible explanation of why there are not many caves in the studied area of Ras Al-Khaimah is that little water penetrates the steep karst slopes of wadis, which does not create ideal conditions for the development of caves, especially in recent climate conditions.

The annual precipitation values here are very low and most of the precipitation falls in the form of downpours causing major surface runoff in the mountainous areas due to large inclination of slopes and the thin-layered impure limestone with marl layers.

Despite that the findings reported here seem insignificant, we believe that the arid karst areas deserve more research attention than they receive now. Speleogenetic and morphogenetic processes in wadis are to a large extent still unresolved and further, more focused research campaigns will surely bring new important scientific findings.

\section{ACKNOWLEDGEMENTS}

In January 2011, following the invitation of Prof. Dr. Asma Al-Farraj, a team from the Karst Research Institute at the Research Centre of the Slovenian Academy of Sciences and Arts went to study the karst and caves in the mountainous regions of the northeastern Emirate of Ras al-Khaimah in the United Arab Emirates. Dr. AlFarraj was interested in the largely unstudied entrances of relatively inaccessible caves located in the middle of mountain slopes that inspired various legends circulating among the local population. The research was also supported by Saud bin Saqr Al Qasimi, sheikh of the RAK emirate. His staff visited our team during the field work and were particularly interested in Dr. Al-Farraj's suggestion that one of the potentially suitable caves to be developed for tourism and that part of the local karst area to be protected as a national park. The team employed an interdisciplinary approach to study the local karst and caves as effectively as possible in the short time available. Primož Presetnik helped to identify bat species. Research was included in Research Programme Karst Research and UNESCO IGCP project No. 598.

\section{REFERENCES}

Al-Farraj, A. \& A.M. Harvey, 2000: Desert pavement characteristics on wadi terrace and alluvial fan surfaces Wadi Al-Bih UAE and Oman.- Geomorphology, 35, 279-297.

Al-Farraj, A. \& A.M. Harvey, 2004: Late Quaternary interactions between aeolian and fluvial processes: a case study in the northern UAE.- Journal of Arid Environments, 56, 2, 235-248.

Aspinall, S. \& P. Hellyer, 2004: Jebel Hafit, A Natural History. pp. 220, Abu Dhabi.
Breesch, L., Swennen, R. \& B. Vincent, 2009: Fluid flow reconstruction in hanging and footwall carbonates: Compartmentalization by Cenozoic reverse faulting in the Northern Oman Mountains (UAE).- Marine and Petroleum Geology, 26, 113-128.

Breton, J.P., Béchennec, F., Le Métour, J., Moen-Maurel, L. \& P. Razin, 2004: Eoalpine (Cretaceous) evolution of the Oman Tethyan continental margin: insights from a structural field study in Jabal Akhdar (Oman Mountains).- GeoArabia, 9, 41-58. 
Burns, S.J., Fleitmann, D., Matter, A., Neff, U. \& A. Mangini, 2001: Speleothem evidence from Oman for continental pluvial events during interglacial periods.- Geology 29, 623-626.

Burns, S.J., Matter, A., Frank, N. \& A. Mangini, 1998: Speleothem-based paleoclimate record from northern Oman.- Geology, 26, 499-502.

Clesceri, L.S., Greenberg, A.E. \& A.D. Eaton, 1998: Standard methods for the examination of water and wastewater. 20 ${ }^{\text {th }}$ Edition, American Public Health Association, Washington.

Edgell, H.S., 1990: Karst in Northeastern Saudi Arabia.J.K.S.A.U, Earth Science, Special issue: 1st Saudi symposium on Earth Science, 3, 81-94.

Embabi, N.S. \& A.A. Ali, 1990: Geomorphology of depressions in the Qatar Peninsula (in Arabic).- Qatar University, pp. 357, Al-Ahleia.

Fleitmann, D. \& A. Matter, 2009: External geophysics, climate and environment, The speleothem record of climate variability in Southern Arabia.- C. R. Geoscience, 341, 633-642.

Fleitmann, D., Burns, S.J., Neff, U., Mangini, A. \& A. Matter, 2003: Changing moisture sources over the last 330,000 years in northern Oman from fluidinclusion evidence in speleothems.- Quaternary Research, 60, 223-232.

Fogg, T., Fogg, P. \& T. Waltham, 2002: Magharet Jebel Hafit - a significant cave in the United Arab Emirates.- Tribulus Journal of the Emirates Natural History Group, 12, 1, 5-14.

Forti, P., Galli, E., Rossi, A., Pint, J. \& S. Pint, 2005: Cave Minerals Of Some Limestone Caves Of Saudi Arabia. Hellenic Speleological Society.- Research made within the MIUR 2002 Project "Morphological and Mineralogical Study of speleothems to reconstruct peculiar karst environments", Kalamos, Hellas.

Glennie, K.W., Boeuff, M.G.A., Hughes-Clarke, M.W., Moody-Stuart, M., Pilaar, W.H.F. \& B.M. Reinhart, 1974: Geology of the Oman Mountains.- Kon. Ned. Geol. Minnhoukundia Genoot. Vern., 33, 423.

Goudie, A., 2009: Cavernous weathering.- In: Gines, A. et al. (eds.) Karst rock features: Karren sculpturing. Carsologica 9. ZRC Publishing, pp. 89-103, Ljubljana.

Gomez-Pujol, L. \& J.J. Fornos, 2009: Microrills.- In: Gines, A. et al. (eds.) Karst rock features: Karren sculpturing. Carsologica 9. ZRC Publishing, pp. 7385, Ljubljana.

Hudson, R.G.S. \& M. Chattan, 1959: The Musandam Limestone (Jurassic to lower Cretaceous) of Oman Arabia.- Notes Memoirs. Moyen-Orient., 3, 69-93.
Hudson, R.G.S., 1960: The Permian and Trias of the Oman peninsula, Arabia.- GeologicaMagazine, 97, 299-308.

Hunt, C.O., 1996: Tafoni (pseudokarst features) in the Maltese Islands.- Cave and Karst Science, 23, 2, 57-62.

Jeannin, P. Y., 1992: Expedition suisse aux Emirats Arabes Unis.- Stalactite (Switzerland), 42, 1, 47-55.

Kempe, K. \& H. Dirks, 2008: Layla Lakes, Saudi Arabia: The World-wide largest lacustrine Gypsum Tufa.Acta Carsologica, 37, 1, 7-14.

Kusky, T., Robinson, C. \& F. El-Baz, 2005: Tertiary-Quaternary faulting and uplift in the northern Oman Hajar Mountains.- Journal of the Geological Society, $162,871-888$.

Lee, J.Y. \& S.H. Song, 2007: Evaluation of groundwater quality in coastal areas: implications for sustainable agriculture.- Environmental Geology, 52, 7, 12311242.

Meigs, P., 1952: Arid and semi-arid climatic types of the world. Procedings, eighth general assembly and seventeenth international congress, International Geographical Union, 135-138, Washington.

Ministry of Agriculture, Soil and water departments, 1993, Hydrology report, N3, 265-269.

Ministry of Communications, 1996, U.A.E. Climate. Pp. 237.

Mulec, J., Krištůfek, V. \& A. Chroňáková, 2012: Comparative microbial sampling from eutrophic caves in Slovenia and Slovakia using RIDACOUNT test kits.- International Journal of Speleology, 41, 1, 1-8.

Mulec, J., Krištůfek, V. \& A. Chroňáková, 2013: Monitoring of microbial indicator groups in caves through the use of $\mathrm{RIDA}^{\otimes} \mathrm{COUNT}$ kits.- Acta Carsologica, $42,2-3$, in press.

Murray, H.H., Pozo, M. \& E. Galán, 2011: An Introduction to Palygorskite and Sepiolite Deposits-Location, Geology and Uses.- Developments in Clay Science, 3, 85-99.

Palmer, A.N., 2007: Cave Geology.- Cave Books, pp. 454, Dayton.

Revelle, R., 1941: Criteria for recognition of sea water in groundwaters.- Transactions - American Geophysical Union, 22, 593-597.

Ricateau, A. \& P.H. Riche, 1980: Geology of the Musandam peninsula (Sultanate of Oman) and its surroundings.- Journal of petroleum geology, 2, 3, 139-152.

Rizk, Z.S. \& A.S. Alsharhan, 2003: Water resources in the United Arab Emirates.- In: Alsharhan, A.S. \& W.W. Wood (eds.) Water Resources Perspectives: Evaluation, Management and Policy. Elsevier, pp. 245-264, Amsterdam. 
Rodriguez-Navarro, C., Doehne, E. \& E. Sebastian, 1999: Origins of honeycomb weathering: The role of salts and wind.- Geological Society of America Bulletin, 111, 8, 1250-1255.

Sadiq, A.M. \& S.J. Nasir, 2002: Middle Pleistocene karst evolution in the State of Qatar, Arabian Gulf.- Journal of Cave and Karst Studies, 64, 2, 132-139.

Searle, M.P., 1988: Structure of the Musandam culmination (Sultanate of Oman and United Arab Emirates) and the Straits of Hormuz syntaxis.- Journal Geological Society, 145, 831-845.

Searle, M.P., James, N.P., Calon, T.J. \& J.D. Smewing, 1983: Sedimentological and Structural evolution of the Arabian continental margin in Musandam Mountains and Dibba zone, U.A.E.- Geological Society of America, Bulletin, 94, 1381-400.

Slabe, T., 1995: Cave rocky relief and its speleogenetical significance.- Zbirka ZRC 10, ZRC Publishing, pp. 128, Ljubljana.

Slabe, T. \& H. Liu, 2009: Significant Subsoil Features.In: Gines, A. et al. (eds.) Karst rock features: Karren sculpturing. Carsologica 9. ZRC Publishing, pp. 123-137, Ljubljana.
Waltham, A.C. \& P.Y. Jeannin, 1998: Forum: Caves in the United Arab Emirates.- Journal Cave and Karst Science, 25, 3, 149-155.

Wycisk, P., Al Assam, M., Akram, S., Al Mulla, M., Schlesier, D., Sefelnasr, A., Al Suwaidi, N.B., Al Mehrizi, M.S. \& A. Ebraheem, 2008: Three-dimensional geological and groundwater flow modelling of drought impact and recharge potentiality in Khatt springs area, Ras Al Khaimah Emirate, UAE.- In: WASTA $8^{\text {th }}$ Gulf Water Conf., Proceedings, 1-14, Bahrain.

Zupan Hajna, N., Al Farraj Al Ketbi, A., Gabrovšek, F., Petrič, M., Slabe, T., Knez, M. \& J. Mulec, 2013: Cave and karst prospection in Ras Al-Khaimah Mountains, Northern United Arab Emirate.- In:

Filippi, M. \& P. Bosak (eds.) $16^{\text {th }}$ International Congress of Speleology, 21 $1^{\text {st }}-28^{\text {th }}$ July 2013, Brno, Czech Republic, International Union of Speleology, Czech Speleological Society, 3, 164-169. 